\title{
Polymorphisms of methylenetetrahydrofolate reductase (MTHFR) and susceptibility to pediatric acute lymphoblastic leukemia in a German study population
}

\author{
Eckart Schnakenberg*1, Andrea Mehles ${ }^{1}$, Gunnar Cario², Klaus Rehe², \\ Kathrin Seidemann ${ }^{2}$, Brigitte Schlegelberger ${ }^{3}$, Holger A Elsner ${ }^{4}$, \\ Karl H Welte ${ }^{2}$, Martin Schrappe ${ }^{2}$ and Martin Stanulla ${ }^{2}$
}

\begin{abstract}
Address: ${ }^{1}$ Institute for Pharmacogenetic and Genetic Disposition, Langenhagen, Germany, ${ }^{2}$ Children's Hospital, Pediatric Hematology and Oncology, Hannover Medical School, Germany, ${ }^{3}$ Institute of Cell and Molecular Pathology, Hannover Medical School, Germany and ${ }^{4}$ Department of Transfusion Medicine, Hannover Medical School, Germany

Email: Eckart Schnakenberg* - es@ipgd.org; Andrea Mehles - andrea.mehles@web.de; Gunnar Cario - cario.gunnar@mh-hannover.de; Klaus Rehe - rehe.klaus@mh-hannover.de; Kathrin Seidemann - seidemann.kathrin@mh-hannover.de;

Brigitte Schlegelberger - schlegelberger.brigitte@mh-hannover.de; Holger A Elsner - elsner.holger-andreas@mh-hannover.de;

Karl H Welte - welte.karl.h@mh-hannover.de; Martin Schrappe - schrappe.martin@mh-hannover.de; Martin Stanulla - stanulla.martin@mh-

hannover.de

* Corresponding author
\end{abstract}

Published: 27 May 2005

BMC Medical Genetics 2005, 6:23 doi:10.1 186/147/-2350-6-23
Received: 16 November 2004

Accepted: 27 May 2005

This article is available from: http://www.biomedcentral.com/I47I-2350/6/23

(c) 2005 Schnakenberg et al; licensee BioMed Central Ltd.

This is an Open Access article distributed under the terms of the Creative Commons Attribution License (http://creativecommons.org/licenses/by/2.0), which permits unrestricted use, distribution, and reproduction in any medium, provided the original work is properly cited.

\begin{abstract}
Background: Methylenetetrahydrofolate reductase (MTHFR) has a major impact on the regulation of the folic acid pathway due to conversion of 5,10-methylenetetrahydrofolate (methylene-THF) to 5-methyl-THF. Two common polymorphisms (677C $>$ T and I298A $>C$ ) in the gene coding for MTHFR have been shown to reduce MTHFR enzyme activity and were associated with the susceptibility to different disorders, including vascular disease, neural tube defects and lymphoid malignancies. Studies on the role of these polymorphisms in the susceptibility to acute lymphoblastic leukemia (ALL) led to discrepant results.
\end{abstract}

Methods: We retrospectively evaluated the association of the MTHFR 677C $>$ T and I298A $>C$ polymorphisms with pediatric ALL by genotyping a study sample of $443 \mathrm{ALL}$ patients consecutively enrolled onto the German multicenter trial ALL-BFM 2000 and 379 healthy controls. We calculated odds ratios of MTHFR genotypes based on the MTHFR 677C $>T$ and 1298A $>C$ polymorphisms to examine if one or both of these polymorphisms are associated with pediatric ALL.

Results: No significant associations between specific MTHFR variants or combinations of variants and risk of ALL were observed neither in the total patient group nor in analyses stratified by gender, age at diagnosis, DNA index, immunophenotype, or TEL/AMLI rearrangement.

Conclusion: Our findings suggest that the MTHFR 677C $>$ T and I298A $>C$ gene variants do not have a major influence on the susceptibility to pediatric ALL in the German population. 


\section{Background}

Methylenetetrahydrofolate reductase (MTHFR) has a major impact on the regulation of the folic acid pathway due to the conversion of 5,10-methylenetetrahydrofolate (methylene-THF) to 5-methyl-THF. Two common nonsynonymous coding region polymorphisms $(677 \mathrm{C}>\mathrm{T}$ and $1298 \mathrm{~A}>\mathrm{C}$ ) in the MTHFR gene were shown to confer reduced enzyme activity in in vitro assays leading to a decreased pool of methyl-THF and the MTHFR variant $677 \mathrm{C}>\mathrm{T}$ was associated with an increased risk of hyperhomocysteinemia, particularly in folate-deficient states [1$4]$. With regard to the MTHFR $677 \mathrm{C}>\mathrm{T}$ polymorphism, results from in vitro assays showed a decrease in enzyme activity to $65 \%$ for the heterozygous and to $30 \%$ for the homozygous state of the 677T variant [5]. For the $1298 \mathrm{~A}>\mathrm{C}$ polymorphism, enzyme activity in vitro is decreased in homozygous variants and, to a lesser extent, in heterozygotes compared with those homozygous for the wild-type allele [6,7]. It is supposed that variants (677TT/1298AA or 677CC/1298CC) of MTHFR increase the level of methylene-THF leading to a subsequent reduction of uracil in DNA. The reduction of uracil decreases the amount of misincorporations of uracil instead of thymidine into DNA. This may protect DNA from doublestrand breaks and, consequently, from chromosomal alterations $[1,8]$. Furthermore, it is assumed that DNA methylation via MTHFR is an important epigenetic feature that modulates DNA methylation status through interaction with folate status [1,9]. Consequently, MTHFR variants are discussed to influence disease processes and several studies in the literature reported on reduced MTHFR enzyme activity and the susceptibility to different disorders, including vascular disease, neural tube defects and lymphoid malignancies [1,2,5,7,8,10-13]. Lymphoid malignancies arise as a consequence of point mutations, chromosomal rearrangements (e.g., chromosomal translocations), and epigenetic alterations in hematopoietic cells making the variant MTHFR an interesting candidate gene for studies on leukemogenesis [14]. However, especially with regard to susceptibility to acute lymphoblastic leukemia (ALL), previous studies led to discrepant results. Although both variants 677T and 1298C have been reported to decrease susceptibility to ALL in children and adults $[8,10,11,13]$, other investigators did not support such associations $[15,16]$. Moreover, the protective effect of MTHFR variants was present only in children before folic acid supplement in pregnancy has been recommended [17]. These results suggest a role for gene-environment interactions in the association of MTHFR with ALL.

In the present study, we analyzed the association of MTHFR variants with pediatric ALL in a German study sample including 443 ALL patients and 379 healthy controls.

\section{Methods \\ Patients and controls}

The present study used data and specimens derived from patients of the ongoing ALL-BFM 2000 trial that is conducted by the Berlin-Frankfurt-Münster (BFM) study group and enrolls pediatric patients from 1 year up to 18 years of age with a diagnosis of ALL from 84 different treatment centers in Germany, Austria, and Switzerland [18]. From July 1999 until the end of February 2001, 497 patients of up to 18 years of age were enrolled onto the clinical trial after informed consent was obtained from the parents or legal guardians. The diagnosis was established in our central reference laboratory by morphological FAB criteria and cytochemistry when at least $25 \%$ lymphoblasts were present in the bone marrow, or when blasts were present in the peripheral blood. The assessments of immunophenotype, cellular DNA content, and positivity for TEL/AML1, BCR/ABL, and MLL/AF4 fusion genes were done as described previously $[19,20]$. Patients were included into the present study, when biological material was available at the study center leading to a study population of 443 patients $(89.7 \%$ of the entire study population) who with regard to clinical characteristics did not significantly differ from the entire study population of 497 patients. Controls $(n=379)$ consisted of blood samples from healthy blood donors (aged between 18-68 years), with no history of malignant neoplastic disease. They were derived through the Department of Transfusion Medicine, Hannover Medical School, Hannover, Germany, and the Clinic Center of Bremen, Bremen, Germany. Individuals included in the present study were of Caucasian descent. The study was approved by the local ethics committee.

\section{Genotyping}

DNA was extracted from peripheral blood or bone marrow samples by using the QIAamp DNA Blood Midi Kit (Qiagen GmbH, Hilden, Germany). Depending on availability, either tumor material or remission samples were used. Analyses of MTHFR variants were performed on a LightCycler ${ }^{\circledast}$ instrument (Roche Diagnostics, Mannheim Germany) using a commercial real-time assay (Artus Biotech, Hamburg, Germany) according to the manufacturer's instructions. Both variants MTHFR $677 \mathrm{C}>\mathrm{T}$ and $1298 \mathrm{~A}>\mathrm{C}$ were analyzed by simultaneous amplification in a single real-time PCR run. Melting curve analyses were performed for both variants after PCR amplification. No differences in the distribution of MTHFR variants were observed between tumor and remission samples (data not shown).

\section{Statistical analysis}

The association of MTHFR variants with risk of disease was examined by use of unconditional logistic regression analysis to calculate odds ratios (OR) and their 95\% 
Table I: Clinical characteristics of patients from trial ALL-BFM 2000

Patients ALL-BFM $2000(\mathrm{n}=443)$

Number of subjects (\%)

\begin{tabular}{cc}
\hline $\begin{array}{c}\text { Gender } \\
\text { Male }\end{array}$ & $268(60.5)$ \\
Female & $175(39.5)$ \\
Age at diagnosis (years) & \\
$<$ I & - \\
I-<6 & \\
$6-<10$ & $264(59.6)$ \\
$\geq 10$ & $80(18.1)$ \\
& $99(22.3)$ \\
DNA indexa & \\
$<$ I.I6 & \\
$\geq$ I.I6 & $258(58.2)$ \\
no result & $48(10.8)$ \\
TEL/AMLI pos. & $137(30.9)$ \\
neg. & $90(20.3)$ \\
unknown & $313(70.7)$ \\
& $40(9.0)$ \\
BCR/ABL pos. & \\
neg. & $9(2.0)$ \\
unknown & $412(93.0)$ \\
MLL/AF4 pos. & $22(5.0)$ \\
neg. & $1(0.2)$ \\
unknown & $394(88.9)$ \\
Immunophenotype & $48(9.9)$ \\
Precursor B & \\
T & \\
Bipenotypic & $344(77.7)$ \\
Unknown & $81(18.3)$ \\
& $4(0.9)$ \\
& $14(3.2)$
\end{tabular}

aRatio of DNA content of leukemic G\%/G' cells to normal diploid lymphocytes.

confidence intervals (CI). $P$ values of $<0.05$ were considered statistically significant. The MTHFR variant was used as a categorical variable in these analyses. The expected frequency of MTHFR variants in controls was analyzed by the Hardy-Weinberg equilibrium test. The SPSS statistical package (SPSS Inc., Chicago, IL) was used for computerized calculations.

\section{Results and Discussion}

Table 1 shows the distribution of clinical characteristics in the study sample of 443 childhood ALL patients from ALL-BFM 2000. Distribution of MTHFR variants within patients and controls are summarized in Table 2. In our control population of 379 healthy individuals the frequencies of MTHFR variants $677 \mathrm{C}>\mathrm{T}$ and $1298 \mathrm{~A}>\mathrm{C}$ were in Hardy-Weinberg equilibrium $\left(677: \chi^{2}=1.81,1298: \chi^{2}\right.$ $=0.05 ; P>0.05)$ and demonstrated strong linkage disequilibrium $(\mathrm{P}<0.001)$. None of the haplotypes was observed more frequently in the ALL group (Tab. 2). MTHFR variants that were previously reported to confer a reduced risk of ALL were similarly distributed in the patient and control group. The frequency of the variant MTHFR 677T was 0.314 in controls and 0.333 in children with ALL. Ogino et al. reported a frequency of 0.320 in a meta-analysis including 5389 individuals [21]. There was also no significant different distribution of the MTHFR $1298 \mathrm{C}$ variant between our patient and control groups. The $1298 \mathrm{C}$ variant occurs with a frequency of 0.367 in controls and 0.314 in patients with ALL. Ogino et al. reported 0.308 in their meta-analysis [21]. The calculated OR and their respective 95\% CI are also shown in Table 2. No significant associations between specific MTHFR variants or combinations of MTHFR variants and risk of ALL were observed neither in the total patient group nor in analyses stratified by gender, age at diagnosis, DNA index, immunophenotype, or TEL/AML1 rearrangement (stratified analyses not shown; strata as shown in Table 1).

With regard to ALL, our results are in contrast to previous findings and do not support the assumption that higher methylene-THF levels due to MTHFR variants lead to a decreased risk of ALL in our study population $[8,10,11,13]$. There are different explanations for these diverging results. The present study included pediatric patients from Germany. The above mentioned studies included adult patients from United Kingdom [8] and Italy [13] but also pediatric patients from United Kingdom [10] or Brazil [11]. These latter two studies on the MTHFR $677 \mathrm{C}>\mathrm{T}$ and $1298 \mathrm{~A}>\mathrm{C}$ polymorphisms in childhood ALL included patients diagnosed between 19921998 and 1991-2000, respectively, while our study included pediatric ALL patients diagnosed after July 1999. Thus, probably a large proportion of patients analyzed in the studies by Wiemels et al. [10] and Franco et al. [11] were born before folic acid supplementation in pregnancy was recommended. In a Canadian study, Krajinovic et al. reported that the protective effect of MTHFR variants was accentuated and present only in children born before 1996 [17]. This may explain the diverging results with regard to pediatric ALL and is further supported by a recent study of Balta and colleagues from Turkey, where in 142 pediatric ALL patients diagnosed between February 2000 and February 2002, no significant association between the MTHFR $677 \mathrm{C}>\mathrm{T}$ polymorphism and ALL was detected [16]. However, the impact of folate metabolism on the risk of ALL may also vary from population to population because of additional gene-environment and gene-gene interactions. For example, in our study population we cannot control for differences in folate status as we have not collected information on dietary intake. Thus, a potentially existing association of MTHFR variants and ALL may be masked by the inability to control for the individual folate status in our study population. Further- 
Table 2: Distribution of MTHFR variants in cases and controls and their association with childhood acute lymphoblastic leukemia in patients from trial ALL-BFM 2000

\begin{tabular}{|c|c|c|c|c|c|}
\hline MTHFR & Cases $(n=443)$ & ) Number (\%) & Controls $(n=379)$ Number $(\%)$ & $\begin{array}{l}\text { Odds ratio }(95 \% \\
\mathrm{Cl})\end{array}$ & $P$ \\
\hline $677 \mathrm{CC} / 1298 \mathrm{AA}$ & 49 & $(I I .1)$ & $45 \quad(11.9)$ & $1.00^{\mathrm{a}}$ & \\
\hline $677 \mathrm{CT} / 1298 \mathrm{AA}$ & 101 & $(22.8)$ & $67 \quad(17.7)$ & $1.38(0.83-2.30)$ & 0.21 \\
\hline 677 TT/I298 AA & 44 & $(9.9)$ & $41 \quad(10.8)$ & $0.99(0.55-1.77)$ & 0.96 \\
\hline $677 \mathrm{CC} / 1298 \mathrm{AC}$ & 101 & $(22.8)$ & $87 \quad(23.0)$ & $1.07(0.65-1.75)$ & 0.80 \\
\hline $677 \mathrm{CT} / \mathrm{I} 298 \mathrm{AC}$ & 100 & $(22.6)$ & $85 \quad(22.4)$ & $1.08(0.66-1.78)$ & 0.76 \\
\hline $677 \mathrm{TT} / 1298 \mathrm{AC}$ & 3 & $(0.7)$ & $(0.5)$ & $1.38(0.22-8.63)$ & 0.73 \\
\hline $677 \mathrm{CC} / 1298 \mathrm{CC}$ & 45 & $(10.2)$ & (13.7) & $0.79(0.45-1.40)$ & 0.43 \\
\hline 677 CT/I298 CC & n.d. & & n.d. & - & - \\
\hline 677 TT//298 CC & n.d. & & n.d. & - & - \\
\hline
\end{tabular}

n.d., not detected; $\mathrm{Cl}$, confidence interval; ${ }^{\text {areference category }}$

more, we cannot exclude potential gene-gene interactions. As several polymorphic key enzymes are involved in folate metabolism, a more comprehensive approach would clearly yield more precise estimates of the association of folate metabolism with risk of ALL. As an additional explanation for diverging results, specifically in subgroups with chromosomal translocations, the potential importance of parental variants and folate status with respect to an in utero pathogenesis of ALL (e.g., MLL/AF4 and TEL/ AML1 fusion gene-positive ALL) should be considered [22]. Lastly, our results may simply be due to chance and small patient numbers. However, with regard to sample size, our study exceeds most other studies reported in the literature, so far. In conclusion, our findings suggest that the MTFHR gene variants analyzed here do not have a major influence on the susceptibility to pediatric ALL in the German population. However, potential effects in rare specific ALL subgroups cannot be excluded.

\section{Conclusion}

We retrospectively evaluated the association of the MTHFR $677 \mathrm{C}>\mathrm{T}$ and $1298 \mathrm{~A}>\mathrm{C}$ polymorphisms with childhood ALL by analyzing a study sample of 443 ALL patients consecutively enrolled onto the German multicenter trial ALL-BFM 2000 and 379 healthy controls. No significant associations between specific MTHFR variants or combinations of MTHFR variants and risk of ALL were observed neither in the total patient group nor in analyses stratified by gender, age at diagnosis, DNA index, immunophenotype, or TEL/AML1 rearrangement. Our findings suggest that the MTHFR $677 \mathrm{C}>\mathrm{T}$ and $1298 \mathrm{~A}>\mathrm{C}$ gene variants do not have a major influence on the susceptibility to pediatric ALL in the German population.

\section{Competing interests}

The author(s) declare that they have no competing interests.

\section{Authors' contributions}

All authors were responsible for the concept of the study. ES and MSt coordinated the study. All authors were involved in sample collection, DNA preparation, genotyping and interpretation of the analyses. MSt and ES did the statistical analyses, drew-up the tables and prepared the manuscript with advice from the other authors. MSch is the chairman of the ALL-BFM 2000 study.

\section{Acknowledgements}

We thank all study participants and Thomas Laue and Dr. Tim Greve for providing kits for MTHFR genotyping.

\section{References}

I. Robien K, Ulrich CM: 5,10-Methylenetetrahydrofolate reductase polymorphisms and leukemia risk: a HuGE minireview. Am J Epidemiol 2003, I 57:57 I-582.

2. Kluijtmans LA, Kastelein IJ, Lindemans ], Boers GH, Heil SG, Bruschke AV, Jukema JW, van den Heuvel LP, Trijbels FJ, Boerma GJ, Verheugt FW, Willems F, Blom HJ: Thermolabile methylenetetrahydrofolate reductase in coronary artery disease. Circulation 1997, 96:2573-2577.

3. Yamada K, Chen Z, Rozen R, Matthews RG: Effects of common polymorphisms on the properties of recombinant human methylenetetrahydrofolate reductase. Proc Natl Acad Sci U S A 200I, 98: |4853-8.

4. Weisberg IS, Jacques PF, Selhub J, Bostom AG, Chen Z, Curtis Ellison $\mathrm{R}$, Eckfeldt JH, Rozen R: The I298A - >C polymorphism in methylenetetrahydrofolate reductase (MTHFR): in vitro expression and association with homocysteine. Atherosclerosis 200I, 1 56:409-15.

5. Frosst P, Blom HJ, Milos R, Goyette P, Sheppard CA, Matthews RG, Boers GJ, den Heijer M, Kluijtmans LA, van den Heuvel LP: A candidate genetic risk factor for vascular disease: a common mutation in methylenetetrahydrofolate reductase. Nat Genet 1995, 10:111-113.

6. Weisberg I, Tran P, Christensen B, Sibani S, Rozen R: A second genetic polymorphism in methylenetetrahydrofolate reductase (MTHFR) associated with decreased enzyme activity. Mol Genet Metab 1998, 64:169-172. 
7. van der Put NM, Gabreels F, Stevens EM, Smeitink JA, Trijbels FJ, Eskes TK, van den Heuvel LP, Blom HJ: A second common mutation in the methylenetetrahydrofolate reductase gene: an additional risk factor for neural-tube defects? Am J Hum Genet 1998, 62:1044-105।.

8. Skibola CF, Smith MT, Kane E, Roman E, Rollinson S, Cartwright RA, Morgan G: Polymorphisms in the methylenetetrahydrofolate reductase gene are associated with susceptibility to acute leukemia in adults. Proc Natl Acad Sci USA 1999, 96:128I0-128I5.

9. Friso S, Choi SW, Girelli D, Mason JB, Dolnikowski GG, Bagley PJ, Olivieri O, Jacques PF, Rosenberg IH, Corrocher R, Selhub J: A common mutation in the 5,10-methylenetetrahydrofolate reductase gene affects genomic DNA methylation through an interaction with folate status. Proc Natl Acad Sci USA 2002, 99:5606-56II

10. Wiemels JL, Smith RN, Taylor GM, Eden OB, Alexander FE, Greaves MF, United Kingdom Childhood Cancer Study Investigators: Methylenetetrahydrofolate reductase (MTHFR) polymorphisms and risk of molecularly defined subtypes of childhood acute leukemia. Proc Natl Acad Sci USA 200I, 98:4004-4009.

II. Franco RF, Simoes BP, Tone LG, Gabellini SM, Zago MA, Falcao RP: The methylenetetrahydrofolate reductase C677T gene polymorphism decreases the risk of childhood acute lymphocytic leukemia. Br J Haematol 200I, II5:616-618.

12. Matsuo K, Suzuki R, Hamajima N, Ogura M, Kagami Y, Taji H, Kondoh E, Maeda S, Asakura S, Kaba S, Nakamura S, Seto M, Morishima Y, Tajima K: Association between polymorphisms of folate-and methionine-metabolizing enzymes and susceptibility to malignant lymphoma. Blood 2001, 97:3205-3209.

13. Gemmati D, Ongaro A, Scapoli GL, Della Porta M, Tognazzo S, Serino ML, Di Bona E, Rodeghiero F, Gilli G, Reverberi R, Caruso A, Pasello $M$, Pellati A, De Mattei M: Common gene polymorphisms in the metabolic folate and methylation pathway and the risk of acute lymphoblastic leukemia and non-Hodgkin's lymphoma in adults. Cancer Epidemiol Biomarkers Prev 2004, 13:787-794.

14. Lin YW, Aplan PD: Leukemic transformation. Cancer Biol Ther 2004, 3: I3-20.

15. Chiusolo P, Reddiconto G, Cimino G, Sica S, Fiorini A, Farina G, Vitale A, Sora F, Laurenti L, Bartolozzi F, Fazi P, Mandelli F, Leone G: Methylenetetrahydrofolate reductase genotypes do not play a role in acute lymphoblastic leukemia pathogenesis in the Italian population. Haematologica 2004, 89:139-| 44.

16. Balta G, Yuksek N, Ozyurek E, Ertem U, Hicsonmez G, Altay C, Gurgey A: Characterization of MTHFR, GSTMI, GSTTI, GSTPI, and CYPIAI genotypes in childhood acute leukemia. Am J Hematol 2003, 73:154- 60.

17. Krajinovic M, Lamothe $S$, Labuda D, Lemieux-Blanchard $E$, Theoret $Y$, Moghrabi A, Sinnett D: Role of MTHFR genetic polymorphisms in the susceptibility to childhood acute lymphoblastic leukemia. Blood 2004, 1 03:252-257.

18. Schrappe M, Reiter A, Zimmermann M, Harbott J, Ludwig WD, Henze $G$, Gadner $H$, Odenwald $E$, Riehm H: Long-term results of four consecutive trials in childhood ALL performed by the ALLBFM study group from 198I to 1995. Berlin-Frankfurt-Munster. Leukemia 2000, 14:2205-2222.

19. Schrappe M, Reiter A, Ludwig WD, Harbott J, Zimmermann M, Hiddemann W, Niemeyer C, Henze G, Feldges A, Zintl F, Kornhuber B, Ritter J, Welte K, Gadner H, Riehm H: Improved outcome in childhood acute lymphoblastic leukemia despite reduced use of anthracyclines and cranial radiotherapy: results of trial ALL-BFM 90. German-Austrian-Swiss ALL-BFM Study Group. Blood 2000, 95:3310-3322.

20. Viehmann S, Borkhardt A, Lampert F, Harbott J: Multiplex PCR - a rapid screening method for detection of gene rearrangements in childhood acute lymphoblastic leukemia. Ann Hematol 1999, 78: 157-162.

21. Ogino S, Wilson RB: Genotype and haplotype distributions of MTHFR677C $>$ T and I298A $>C$ single nucleotide polymorphisms: a meta-analysis. J Hum Genet 2003, 48:I-7.

22. Labuda D, Krajinovic M, Sabbagh A, Infante-Rivard C, Sinnett D: Parental genotypes in the risk of a complex disease. Am J Hum Genet 2002, 71:193-197.

\section{Pre-publication history}

The pre-publication history for this paper can be accessed here:

http://www.biomedcentral.com/1471-2350/6/23/prepub
Publish with Biomed Central and every scientist can read your work free of charge

"BioMed Central will be the most significant development for disseminating the results of biomedical research in our lifetime. "

Sir Paul Nurse, Cancer Research UK

Your research papers will be:

- available free of charge to the entire biomedical community

- peer reviewed and published immediately upon acceptance

- cited in PubMed and archived on PubMed Central

- yours - you keep the copyright
Biomedcentral 